\title{
Production rates and characteristics of fecal pellets of the copepod Acartia tonsa under simulated phytoplankton bloom conditions: implications for vertical fluxes
}

\author{
Mari Butler, Hans G. Dam* \\ Department of Marine Sciences, University of Connecticut, Groton, Connecticut 06340-6097, USA
}

\begin{abstract}
Over the course of a bloom, the quantity and quality of algae available for copepods to eat may vary dramatically. The effects of varying phytoplankton concentration and quality on fecal pellet production rates and fecal pellet characteristics of the calanoid copepod Acartia tonsa were examined in the laboratory. Bloom conditions were simulated by feeding copepods cells of the diatom Thalassiosira weissflogii grown in batch cultures. Experiments were run when algae were rapidly growing (early bloom) and when algae were in stationary growth phase (late bloom) at concentrations ranging from 0 to 3200 cells $\mathrm{ml}^{-1}$. Daily pellet production rates and volume, density, and carbon and nitrogen content of pellets were measured. Results show that for a given algal growth stage, pellet production rate and pellet volume increase linearly with cell concentration up to a critical point, beyond which no further increases in these parameters occur. In general, (1) maximum pellet volumes were higher when copepods ate late-bloom cells, (2) pellet densities were higher when copepods ate early-bloom cells, and (3) volume-specific pellet carbon was higher when copepods ate early-bloom cells. Sinking rates of pellets were estimated from an empirical model based on pellet volume and density. Sinking rates of

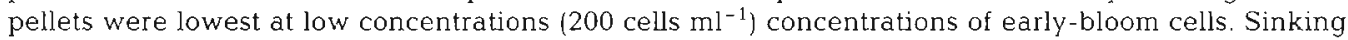
rates were highest at high concentrations (2000 cells $\mathrm{ml}^{-1}$ ) of early-bloom cells. Sinking rates of fecal pellets were relatively high regardless of food concentration when copepods ate late-bloom cells. Daily volume-specific fecal matter produced per copepod was also calculated. Maximum values of total fecal matter index were higher when copepods ate early-bloom cells. Our results indicate that copepod fecal pellets change in a predictable manner aver the course of a bloom. We conclude that copepod fecal pellets may play different roles in recycling and vertically transporting carbon over the course of a phytoplankton bloom.
\end{abstract}

KEY WORDS: Fecal pellets · Phytoplankton blooms · Carbon flux · Food quality · Zooplankton

\section{INTRODUCTION}

The sinking flux of copepod fecal pellets may be a significant fraction of export production (Turner \& Ferrante 1979, Small et al. 1987, Noji 1991). However, the magnitude of this flux may vary seasonally depending, among other factors, on the amount and type of food available for copepods to eat. Factors which contribute to whether fecal pellets will be a part of the export flux include pellet production rates, decomposition rates

- Addressee for correspondence and sinking rates. Pellet production rate is influenced by ingestion rates and assimilation efficiency (Paffenhöfer \& Knowles 1979, Angel 1984, Ayukai \& Nishizawa 1986). Pellet decomposition rate varies with water temperature, and microbial and metazoan activity (Honjo \& Roman 1978, Turner 1979, Jacobsen \& Azam 1984, Lampitt et al. 1990, Roy \& Poulet 1990. Noji et al. 1991). Sinking rate may be the most important parameter contributing to whether or not a pellet successfully transports its contents to deeper water before it is degraded. A slowly sinking pellet is more likely to decompose and become part of the recycled materials before it exits the euphotic zone (Dagg \& 
WaIser 1986, Small et al. 1987). Factors which contribute to the sinking velocity include size, density and shape (Fowler \& Small 1972, Turner 1977, Small et al. 1979, Komar et al. 1981). Turbulence in the water column and the presence or absence of a peritrophic membrane and microbial gas production inside the peritrophic membrane might also affect a pellet's sinking rate (Honjo \& Roman 1978, Alldredge et al. 1987, Bathmann et al. 1987).

Experimental measurements (Turner 1977. Small et al. 1979) and mathematical modeling (Komar et al. 1981) indicate that a pellet's sinking rate increases as pellet size increases. A positive relationship has also been noted between copepod size and pellet size suggesting that larger copepods produce larger fecal pellets (Paffenhöfer \& Knowles 1979, Small et al. 1987). The composition of the pellets might also affect the density, size, and sinking rate (Bienfang 1980, Urban et al. 1993).

Because pellets may provide a portion of the nutrient requirements for bacteria as well as for protozoans and metazoans in the water column and in the benthos, their composition is of great interest. Fecal pellets may provide an important source of organic carbon, nitrogen and silica to the benthos (Schrader 1971, Urrère \& Knauer 1981, Tanoue 1985a, b, Tanoue \& Hara 1986, Small \& Ellis 1992).

Phytoplankton blooms, particularly in temperate regions, often result in high sedimentation of intact cells and zooplankton fecal pellets (review in Legendre 1990). Penry \& Frost (1991) hypothesized that fecal pellets produced early in a bloom may have a greater amount of labile organic materials in comparison with pellets produced late in a bloom. However, despite the wealth of studies on copepod fecal pellets, there has been no systematic study examining the role of changing food conditions during a phytoplankton bloom on the production rates and characteristics of copepod fecal pellets. In this study we contrasted the pellet production rates, and pellet characteristics (volume, density, carbon and nitrogen content) of the copepod Acartia tonsa under laboratory-simulated conditions typical of an early and a late phytoplankton bloom. From these measurements we draw conclusions as to the importance of copepod fecal pellets as agents of carbon export throughout the development of a phytoplankton bloom in a temperate area.

\section{MATERIALS AND METHODS}

All experiments were run in a walk-in environmental chamber at $16 \pm 1^{\circ} \mathrm{C}$ on a $12: 12 \mathrm{~h}$ light:dark cycle. Experiments were run when the food medium fed to the copepods was in exponential or stationary growth phases to simulate early- and late-phytoplanktonbloom conditions. In the first type of experiment [referred to as the pellet production (PP) experiment]. pellet production rates and pellet volumes were measured as a function of food concentration (Table 1). In the second type of experiment [referred to as the largescale pellet collection (LSPC) experiment], copepods were fed either high or low phytoplankton concentrations and the density (specific gravity) and carbon and nitrogen content of the fecal pellet produced were measured (Table 1).

Phytoplankton cultures. Cultures of the diatom Thalassiosira weissflogii ( $13 \mu \mathrm{m}$ equivalent spherical diameter. ESD) were used in all experiments. Cultures, bubbled with air, were maintained in $10 \mathrm{l}$ polycarbonate carboys (PP Expts 2 \& 3 and all LSPC Expts) and 0.51 Erlenmeyer flasks (PP Expt 1) containing $\mathrm{f} / 2$ medium (Guillard 1975). Nutrients were not added after initial inoculation. One carboy was set up per experiment Cultures were kept in the walk-in environmental chamber described above. Light intensity was nominally $120 \mu \mathrm{E} \mathrm{m}^{-2} \mathrm{~s}^{-1}$. Particle concentrations (subtriplicates) were measured with an Elzone 280 particle counter. Chlorophyll concentration was measured (subtriplicates) with a Turner Designs fluorometer. Particle and chlorophyll concentration were measured daily in PP Expts 2 \& 3 and all LSPC Expts. CHN measurements were also made at least every other day using a Control Equipment, Model 240HA. CHN ana-

Table 1 Thalassiosira weissflogii. Growth rate, chlorophyll (chl), carbon and nitrogen content per cell, and $\mathrm{C} / \mathrm{N}$ ratio during experiments. Growth rates were estimated, assuming exponential growth, from the change in particle number in the culture during the $24 \mathrm{~h}$ previous to the experiment. Carbon and nitrogen per cell data are from duplicate measurements of the stock culture used to make the dilutions used in the experiments. Chlorophyll measurements of each dilution were made in triplicate, and the chl cell ${ }^{-1}$ is reported as the mean. -: no data (see 'Materials and methods')

\begin{tabular}{|c|c|c|c|c|c|c|}
\hline & Expt & $\begin{array}{l}\text { Growth } \\
\text { rate, } d^{-1}\end{array}$ & $\begin{array}{l}\mathrm{pg} \mathrm{chl} \\
\text { cell }\end{array}$ & $\begin{array}{l}\operatorname{pg~C} \\
\text { cell }\end{array}$ & $\begin{array}{l}\operatorname{pg} \mathrm{N} \\
\mathrm{cell}^{-1}\end{array}$ & $\begin{array}{l}\mathrm{C} / \mathrm{N} \\
\text { (wt) }\end{array}$ \\
\hline \multicolumn{7}{|c|}{ Pellet production experiments (PP) } \\
\hline $\operatorname{Jan} 4$ & $1 \mathrm{a}$ & - & - & - & - & - \\
\hline $\operatorname{Jan} 7$ & $1 b$ & - & - & - & - & - \\
\hline Jun 26 & $2 a$ & 0.45 & 6.9 & 135 & 28 & 4.9 \\
\hline Jul 22 & $2 b$ & 0.18 & 10.8 & 179 & 23 & 7.8 \\
\hline Sep 4 & $3 a$ & 0.35 & 8.1 & 99 & 19 & 5.4 \\
\hline Sep 16 & $3 b$ & -0.02 & 15.6 & 374 & 51 & 7.4 \\
\hline \multicolumn{7}{|c|}{ Large-scale pellet collections (LSPC) } \\
\hline Aug 11 & 1 & 0.15 & 7.5 & 187 & 34 & 5.5 \\
\hline Aug 25 & 2 & -0.04 & 16.7 & 693 & 91 & 7.6 \\
\hline Sep 8 & 3 & 0.40 & 8.4 & 149 & 23 & 6.4 \\
\hline Sep 23 & 4 & -0.12 & 16.1 & 470 & 60 & 7.8 \\
\hline
\end{tabular}


lyzer. On days of experiments duplicate CHN measurements were made (Table 1). In PP Expt 1, 2 cultures were started at the same time. One was used 1 wk after inoculation while still growing rapidly, and the other was used 2 wk after inoculation while not growing as rapidly. Particle and chlorophyll concentrations were only measured on days of experiments. Carbon and nitrogen content of the algae in PP Expt 1 were not measured.

Collection of copepods. Adult female Acartia tonsa (Copepoda: Calanoida) collected from Long Island Sound, New York, USA, near the entrance to Pine Island Bay $\left(41^{\circ} 19^{\prime} \mathrm{N}, 72^{\circ} 4^{\prime} \mathrm{W}\right)$ were used in all experiments. Specimens were collected with $202 \mu \mathrm{m}$ mesh nets fitted with a solid cod-end to minimize damage to the specimens. Immediately after capture, copepods were placed in a bucket with surface water and transported back to the laboratory where they were anesthetized with MS-222 (0.58 $\left.\mathrm{g} \mathrm{l}^{-1}\right)$ and sorted using a dissecting microscope. The concentration of the anesthetic is the lowest dose at which female $A$. tonsa are effectively immobilized without any apparent negative effects afterwards (Durbin et al. 1990). Copepods were allowed to recover overnight before they were used in any experiments. After recovering, copepods did not display any unusual swimming behaviors, and only those females that appeared healthy and had all appendages intact were used in experiments.

Pellet production experiments. Approximately 30 adult females were selected and placed in an aerated beaker containing filtered sea water. Approximately 100 cells $\mathrm{ml}^{-1}$ of Thalassiosira weissflogii were added to the water. The next morning, about $21 \mathrm{~h}$ later, females were gently wet-sieved through a $64 \mu \mathrm{m}$ Nytex mesh and divided into 7 groups (see below). Dilutions of algae were made by mixing a portion of the batch culture with $0.2 \mu \mathrm{m}$ filtered sea water. Experiments were run during exponential and stationary growth phases (Table 1). When rapidly growing algae were used in an experiment, the nutrients used to make $\mathrm{f} / 2$ medium were added to the dilutions to ersure the algae would not be nutrient limited.

The 7 groups of females were placed for $2 \mathrm{~h}$ in $1 \mathrm{l}$ acclimation beakers each containing a different concentration of algae ranging from 0 to 1500 cells $\mathrm{ml}^{-1}$ (PP Expt 1) or 0 to 3200 cells $\mathrm{ml}^{-1}$ (PP Expts 2 \& 3). Individual females from each group were placed in $1000 \mathrm{ml}$ (PP Expt 1) or $500 \mathrm{ml}$ (PP Expts 2 \& 3) polycarbonate bottles ( 4 replicates in PP Expt 1, 6 replicates in PP Expts 2 \& 3) filled with food suspension of the same concentration used during acclimation. Bottles were placed on a plankton wheel rotating at $2 \mathrm{rpm}$ for $24 \mathrm{~h}$.

After this, bottles were removed from the wheel, and the time and the condition of the copepods were noted. Bottles with dead copepods were not used in the analy- sis. The contents of each bottle were gently sieved through a $30 \mu \mathrm{m}$ Nytex mesh to retain the females and fecal pellets. Contents of the bottles were preserved in $4 \%$ formalin.

At a later date, prosome length and maximum width of females were measured using a dissecting microscope and an image analysis system (Olympus Cue-2, with Panasonic WV-CV50 camera). Copepod prosome volume was estimated assuming a cylindrical shape. Pellets were counted and pellet production rates were determined. The length and width of 30 pellets were measured. If there were less than 30 pellets per bottle, all were measured. The volume of pellets was estimated assuming a cylindrical shape. Pellet production rate and average volume per pellet were plotted versus algal concentration. An Ivlev equation was used to fit these data:

$$
\begin{gathered}
P P R=P P R_{\max }\left(1-\mathrm{e}^{-\alpha C}\right) \\
V O L=V O L_{\max }\left(1-\mathrm{e}^{-\alpha C}\right)
\end{gathered}
$$

where $P P R=$ pellet production rate $\left(\right.$ pellets copepod ${ }^{-1}$ $\left.\mathrm{d}^{-1}\right), V O L=$ average estimated volume per pellet $\left(\mu \mathrm{m}^{3}\right), P P R_{\max }=$ maximum pellet production rate, $V O L_{\max }=$ maximum average estimated volume per pellet, $C=$ food concentration (cells $\mathrm{ml}^{-1}$ ), $\alpha=$ rate at which $P P R_{\max }$ or $V O L_{\max }$ is approached. This model was fitted using the Marquardt estimate as computed by Statgraphics (Statgraphics User's Guide 1986).

Large-scale pellet collection experiments. Two groups of approximately 300 females each were placed in $4 \mathrm{l}$ beakers containing aerated $0.2 \mu \mathrm{m}$ filtered sea water. Enough Thalassiosira weissflogii cells to bring the concentration of the filtered sea water to approximately 200 cells $\mathrm{ml}^{-1}$ were added to each beaker. About halfway through the $12 \mathrm{~h}$ acclimation period, enough algae to bring one of the acclimation chambers to approximately 2000 cells $\mathrm{ml}^{-1}$ were added, creating 2 different treatments, a high and a low food concentration. At the end of the acclimation period, females from each group were gently rinsed onto a wet sieve and transferred to a 20 I plastic bucket filled with the same concentration of the food suspension used during the last $6 \mathrm{~h}$ of acclimation. In each bucket a screen fitted with a $30 \mu \mathrm{m}$ mesh had been placed at the bottom and on top of this screen another one fitted with $202 \mu \mathrm{m}$ mesh. The bottom screen collected fecal pellets while the top screen separated females from the pellets. In all cases the experiments started at approximately 04:00 h and terminated at 08:00 h (part of the dark period), which has been reported to be a time of relatively high ingestion rates for this species (Stearns 1986, Durbin et al. 1990). This time frame was chosen in an effort to obtain the maximum number of pellets in the shortest time, thereby reducing microbial effects due to long incubation periods (Honjo \& Roman 1978 . 
Turner 1979j. At the end of incubation, the copepods were removed from each pellet collector by gently lifting the $202 \mu \mathrm{m}$ mesh insert. Several copepods were saved and preserved for later examination. Pellets were then removed by gently lifting the $30 \mu \mathrm{m}$ mesh insert. No quantitative recovery of pellets was necessary for the purposes of this experiment. The pellets were split into 2 fractions, one for density determination and the other for CHN analysis. The fraction to be chemically analyzed was immediately frozen in a $25 \mathrm{ml}$ scintillation vial.

Pellet density. Fecal pellet density was measured in a density gradient using a modification of the method of Schwinghamer et al. (1991). Using NALCO1060 colloidal silica, sucrose, and distilled water, 6 dilutions ranging in density from about 1.04 to $1.39 \mathrm{~g} \mathrm{~cm}^{-3}$ were made. Dilutions were brought to a $\mathrm{pH}$ of approximately 8.0 using Tris- $\mathrm{HCl}$ and Tris-base. A $2 \mathrm{ml}$ volume of each dilution was poured into a $15 \mathrm{ml}$ centrifuge tube beginning with the most dense and finishing with the least dense. These density gradients were allowed to sit overnight. Fresh pellets collected at about 08:00 h from the pellet collectors were examined under a dissecting microscope and rinsed several times in filtered sea water. Using a micropipette, pellets were picked individually and placed in about $1 \mathrm{ml}$ of filtered sea water. They were then gently placed on top of the density gradients. Three subreplicates of 50 pellets for each algal concentration were set up. The 6 centrifuge tubes were then placed in a Fisher Scientific table-top centrifuge for $30 \mathrm{~min}$ at approximately $3000 \mathrm{rpm}$. After centrifugation, $2 \mathrm{ml}$ aliquots were removed from each tube, beginning with the most dense layer, using a peristaltic pump and a micropipette that was carefully inserted to the bottom of the centrifuge tube. Each aliquot was then carefully weighed in a Fisher Scientific, A-160 balance to $0.10 \mathrm{mg}$ and a more precise volume determined using a $5 \mathrm{ml}$ Hamilton syringe calibrated to $0.10 \mathrm{ml}$. The average density of each aliquot was calculated by dividing the mass by the volume.

These aliquots were then each examined under a dissecting microscope. Pellets were counted and their lengths and widths measured. The density of the aliquot where the pellets settled out was assumed to be the density of the pellets

Mann-Whitney U-tests (Sokal \& Rohlf 1981) were used to compare average estimates of volumes and densities between treatments. Two sets of experiments were conducted. Each set consisted of an experiment where copepods were fed rapidly growing algae and an experiment where copepods were fed slowly growing algae.
Each experiment had 2 treatments, a high food concentration and a low food concentration. Other statistical analyses were also conducted including a 2-way ANOVA (Sokal \& Rohlf 1981) to determine whether food concentration or food quality had more of an effect on the density of pellets.

Using the densities determined from the gradients and the volumes estimated from length and width measurements, sinking rates were calculated using a variation of Stoke's law (Komar et al. 1981):

$$
w_{\mathrm{s}}=0.0790 \frac{1}{v}\left(\rho_{\text {particle }}-\rho_{\text {water }}\right) g L^{2}(L / D)^{-1.664}
$$

where $w_{s}=$ sinking velocity $\left(\mathrm{cm} \mathrm{s}^{-1}\right), v=$ viscosity of sea water $\left(\mathrm{g} \mathrm{cm}^{-1} \mathrm{~s}^{-1}\right), g=$ acceleration due to gravity (981 $\left.\mathrm{cm} \mathrm{s}^{-2}\right), L=$ length of pellet $(\mathrm{cm}), D=$ diameter of pellet $(\mathrm{cm}), \rho=$ density $\left(\mathrm{g} \mathrm{cm}^{-3}\right)$. Calculated sinking rates of pellets produced under different treatments were compared using a 2-way ANOVA where the 2 factors influencing the response variable, sinking rate, were food quality and food concentration.

Carbon and nitrogen content of pellets. Pellets for $\mathrm{CHN}$ analysis were thawed out and rinsed with filtered sea water. Using a micropipette, approximately 300 pellets were isolated and rinsed onto a combusted $\mathrm{GF} / \mathrm{C}$ filter. The filter was placed in a petri dish and dried for a minimum of $48 \mathrm{~h}$ at $60^{\circ} \mathrm{C}$. No more than $3 \mathrm{~h}$ elapsed between pellets being thawed and filters being placed in the drying oven. Carbon and nitrogen content of the fecal pellets, corrected for filter blank, were measured with a Control CHN analyzer (Control Equipment, Model 240HA)

\section{RESULTS}

\section{Pellet production rates}

Fig. 1 illustrates the relationship between pellet production rate and cell concentration. Maximum pellet

Table 2. Thalassiosira weissflogii. Summary of Ivlev model fits to the pellet production data. $P P R_{\max }=$ maximum pellet production rate (pellets copepod $d^{-1} \mathrm{~d}^{-1}$ ). Values in parentheses are standard errors. For other parameters see Eq. (2) in text. n: number of observations used in model. fit. $r^{2}$ fraction of the variance explained by the model fit

\begin{tabular}{|cccccc|}
\hline PP Expt & Date & $P P R_{\max }$ & $\alpha$ & $\mathrm{n}$ & $\mathrm{r}^{2}$ \\
\hline 1a & Jan 4 & $100.96(32.22)$ & $2.2 \times 10^{-3}\left(1.4 \times 10^{-3}\right)$ & 18 & 0.57 \\
1b & Jan 7 & $46.76(4.68)$ & $6.3 \times 10^{-3}\left(3.1 \times 10^{-3}\right)$ & 18 & 0.69 \\
2a & Jun 26 & $88.76(8.68)$ & $2.9 \times 10^{-3}\left(0.9 \times 10^{-3}\right)$ & 27 & 0.74 \\
2b & Jul 22 & $56.18(3.92)$ & $1.4 \times 10^{-2}\left(0.6 \times 10^{-3}\right)$ & 38 & 0.48 \\
3a & Sep 4 & $96.35(20.90)$ & $0.6 \times 10^{-3}\left(0.3 \times 10^{-3}\right)$ & 25 & 0.77 \\
3b & Sep 16 & $95.27(6.22)$ & $6.8 \times 10^{-3}\left(1.9 \times 10^{-3}\right)$ & 41 & 0.62 \\
\hline
\end{tabular}



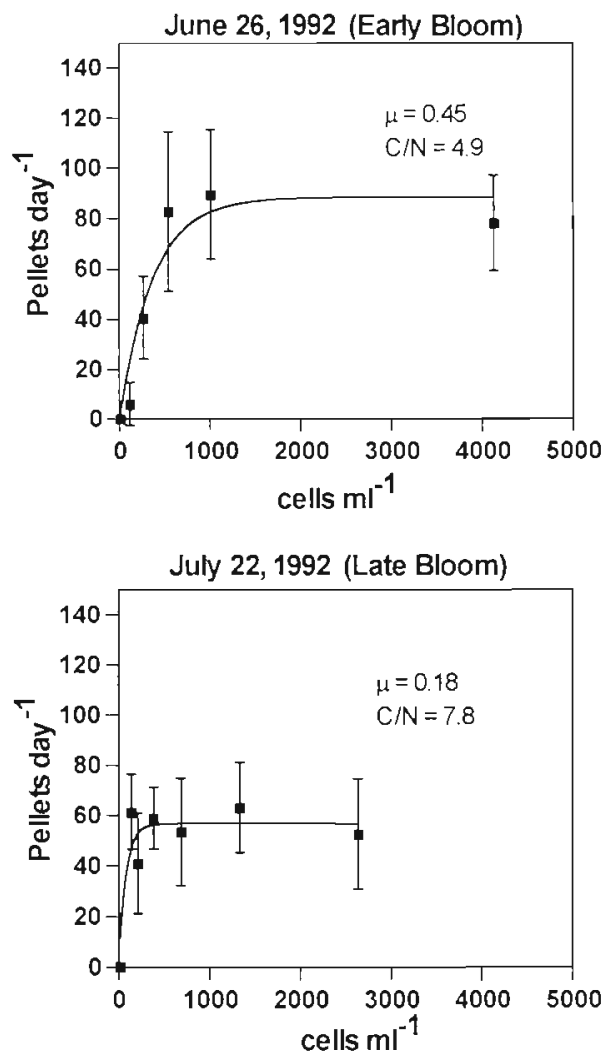

Fig. 1. Thalassiosira weissflogii. Fecal pellet production rates for experiments done on June 26 and July 22, 1992. Each point represents the mean \pm standard deviation of the pellet production rate of 6 replicates at 6 different algal concentrations. $\mu$ and $\mathrm{C} / \mathrm{N}$ refer to the cell culture fed to the copepods

production rates and $\alpha$-values, the rates at which maxima are approached, are shown in Table 2 in which ' $a$ ' and ' $b$ ' designate experiments in which rapidly growing algae with lower $\mathrm{C} / \mathrm{N}$ ratio and slowly growing algae with relatively high $\mathrm{C} / \mathrm{N}$ ratio, respectively, were used (Table 1). The former experiments represent conditions likely to be found early in a bloom while the latter represent conditions later in a bloom. Examination of Table 2 and Fig. 1 generally shows that maximum pellet production rates tend to be higher when copepods were fed cells representative of early-bloom conditions. This trend is followed in all 3 experiments. However, the rates at which maximum pellet production rates were approached $(\alpha)$ were higher when copepods were fed cells representative of late-bloom conditions. Saturation concentrations (here defined as food concentration at which $P P R$ is within $95 \%$ of $P P R_{\text {max }}$ ) were lower when copepods were fed late-bloom cells. This
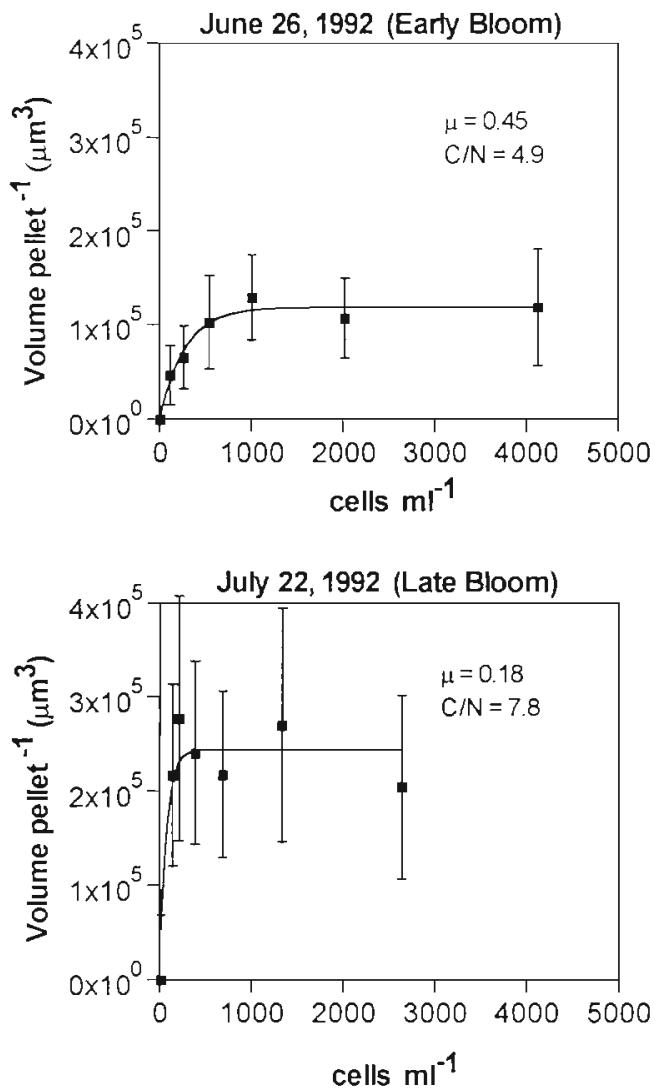

Fig. 2. Thalassiosira weissflogii. Average volume of individual pellets from pellet production experiments done on June 26 and July 22, 1992. Each point represents the mean \pm standard deviation of 6 replicates. Thirty pellets per replicate were measured. If a replicate had $<30$ pellets, all intact pellets were measured. $\mu$ and $\mathrm{C} / \mathrm{N}$ refer to the cell culture fed to the copepods

trend holds whether food concentration is expressed in terms of cells, $\mathrm{C}$ or $\mathrm{N} \mathrm{ml}^{-1}$.

The relationship of pellet volume vs cell concentration is illustrated in Fig. 2. Female Acartia tonsa tended to produce pellets with higher maximum volume when fed late-bloom cells (Table 3).

Table 3. Thalassiosira weissflogii. Summary of lvlev model fits to average volume of pellets. $V O L_{\text {rnax }}$ : maximum volume pellet ${ }^{-1}\left(\mu \mathrm{m}^{3}\right)$. Other parameters as in Table 2. Values in parentheses are standard errors

\begin{tabular}{|clcccc|}
\hline PP Expt & Date & VOL $_{\max } \times 10^{-5}$ & $\alpha$ & $\mathrm{n}$ & $\mathrm{r}^{2}$ \\
\hline 1a & Jan 4 & $1.52(0.16)$ & $1.1 \times 10^{-2}\left(4.2 \times 10^{-3}\right)$ & 18 & 0.57 \\
1b & Jan 7 & $2.24(0.23)$ & $1.2 \times 10^{-2}\left(4.8 \times 10^{-3}\right)$ & 18 & 0.62 \\
2a & Jun 26 & $1.05(0.09)$ & $1.2 \times 10^{-2}\left(6.8 \times 10^{-3}\right)$ & 33 & 0.32 \\
2b & Jul 22 & $2.42(0.11)$ & $1.5 \times 10^{-2}\left(4.5 \times 10^{-3}\right)$ & 38 & 0.65 \\
3a & Sep 4 & $1.88(0.18)$ & $9.0 \times 10^{-3}\left(5.1 \times 10^{-3}\right)$ & 25 & 0.40 \\
3b & Sep 16 & $1.94(0.09)$ & $1.6 \times 10^{-2}\left(5.2 \times 10^{-3}\right)$ & 41 & 0.62 \\
\hline
\end{tabular}




\section{Pellet density}

Analysis of pellets from the large-scale pellet collection experiments suggest that copepods fed earlybloom cells produced slightly denser pellets than those fed late-bloom cells (Fig. 3). Food concentration did not appear to have as great an effect on pellet density as food quality.

To examine how food concentration affected pellet density, we pooled all pellets produced from low concentration treatments and compared them to all pellets produced at high food concentrations. The average densities of these 2 groups, 1.15 and $1.16 \mathrm{~g} \mathrm{~cm}^{-3}$, were not significantly different (Fig. 3). The same exercise was repeated to examine how food quality affects pellet density. Pooling all pellets produced in LSPC Expts $1 \& 3$ (early-bloom algae, mean $\rho=1.17 \mathrm{~g} \mathrm{~cm}^{-3}$ ) and comparing them to all pellets produced in Expts $2 \& 4$ (late-bloom algae, mean $\rho=1.14 \mathrm{~g} \mathrm{~cm}^{-3}$ ) shows that pellets from LSPC Expts 1 \& 3 were significantly denser than pellets from LSPC Expts 2 \& 4 (MannWhitney $U$-test, $\mathrm{p}<0.05$ ) (Fig. 3). A 2-way ANOVA verified that food quality (early-bloom vs late-bloom condition) had a significant effect on pellet density ( $\mathrm{p}<$ 0.05 ) but that neither food concentration nor the interaction of food concentration and food quality had an effect on pellet density ( $p>0.05)$.

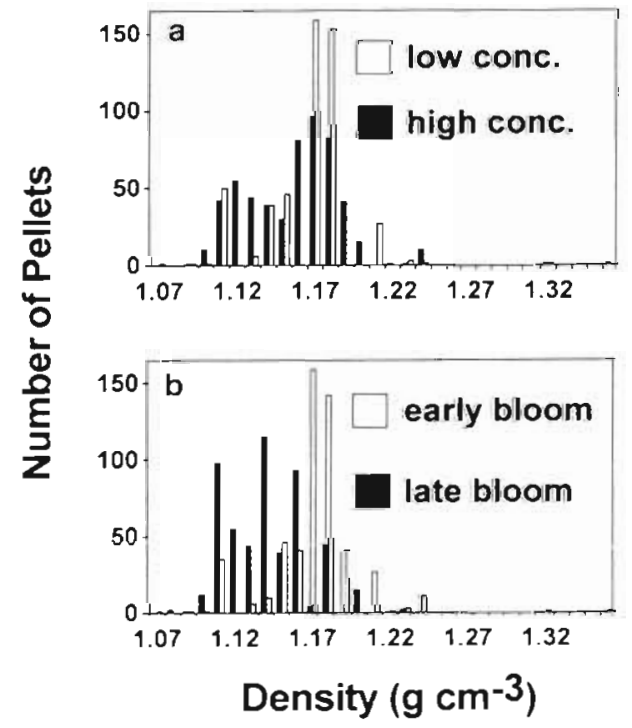

Fig. 3. Thalassiosira weissflogii. Frequency plots showing measured pellet densities pooled together by treatment. (a) Frequency of pellet density pooled together by food concentration. Empty bar: all pellets from low food concentrations regardless of food quality. Filled bar: all pellets from high food concentrations regardless of food quality. (b) Pellets pooled by tood quality regardless of food concentration. Empty bar: all pellets from LSPC Expts 1 \& 3 (high-quality food). Filled bar: all pellets from LSPC Expts 2 \& 4 (low-quality food)

\section{Pellet volume}

Analysis of pellets collected during the large-scale pellet collection experiments indicates that when specimens were fed early-bloom cells (LSPC Expts 1 \& 3 in Fig. 4), they produced pellets of lower volume at low than at high cell concentrations (Mann-Whitney $U$ test, $\mathrm{p}<0.05)$. When copepods were fed late-bloom cells (LSPC Expts $2 \& 4$ ), the effect of cell concentration was not as clear. In LSPC Expt 2, pellet volumes were barely smaller at low than at high cell concentration (Mann-Whitney $U$-test, $p=0.04$ ). On the other hand, in LSPC Expt 4, pellet volumes were greater at low than at high cell concentrations (Mann-Whitney $U$-test, $\mathrm{p}<$ 0.05). These results from LSPC Expt 4 are inconsistent with those obtained during LSPC Expt 2 and the pellet production experiments (e.g. Fig. 2). A 2-way ANOVA (after log transformation to normalize the data) suggested that the interaction of cell quality and concentration on pellet volume may be important $(p=0.06)$.

\section{Sinking rates}

Sinking rates calculated using Stoke's law ranged from 9.1 to $21.4 \mathrm{~m} \mathrm{~d}^{-1}$ (Table 4). Sinking rates were highest when copepods were fed high concentrations of early-bloom cells. Examination of Eq. (3) indicates that factors that result in increases in primarily pellet size and secondarily pellet density will accelerate sinking rates. Thus, it is apparent here that sinking rates follow the same trend as pellet volume, but not necessarily pellet density. Large pellets were produced at high cell concentrations, and these pellets have the highest sinking rates. The smallest pellets produced at low concentrations of early-bloom cells have the lowest sinking rates despite their relatively high densities.

Table 4. Thalassiosira weissflogii. Estimated sinking rates calrulated from Eq. (4). Calculations assume $v=0.011 \mathrm{~g} \mathrm{~cm}^{-1} \mathrm{~s}^{-1}$ and $\rho=1.013 \mathrm{~g} \mathrm{~cm}^{3}$ (see Eq. 3)

\begin{tabular}{|cllcc|}
\hline $\begin{array}{c}\text { LSPC } \\
\text { Expt }\end{array}$ & Date & $\begin{array}{c}\text { Bloom } \\
\text { condition }\end{array}$ & $\begin{array}{c}\text { Algal conc. } \\
\text { (cells ml }^{-1} \text { ) }\end{array}$ & $\begin{array}{c}\text { Mean sinking } \\
\text { rate (m d }\end{array}$ \\
\hline 1 & Aug 11 & Early & 314 & 10.82 \\
1 & Aug 11 & Early & 2405 & 17.35 \\
2 & Aug 25 & Late & 266 & 13.50 \\
2 & Aug 25 & Late & 1954 & 12.40 \\
3 & Sept 8 & Early & 271 & 9.11 \\
3 & Sept 8 & Early & 2301 & 21.40 \\
4 & Sept 23 & Late & 262 & 18.31 \\
4 & Sept 23 & Late & 2343 & 16.25 \\
\hline
\end{tabular}



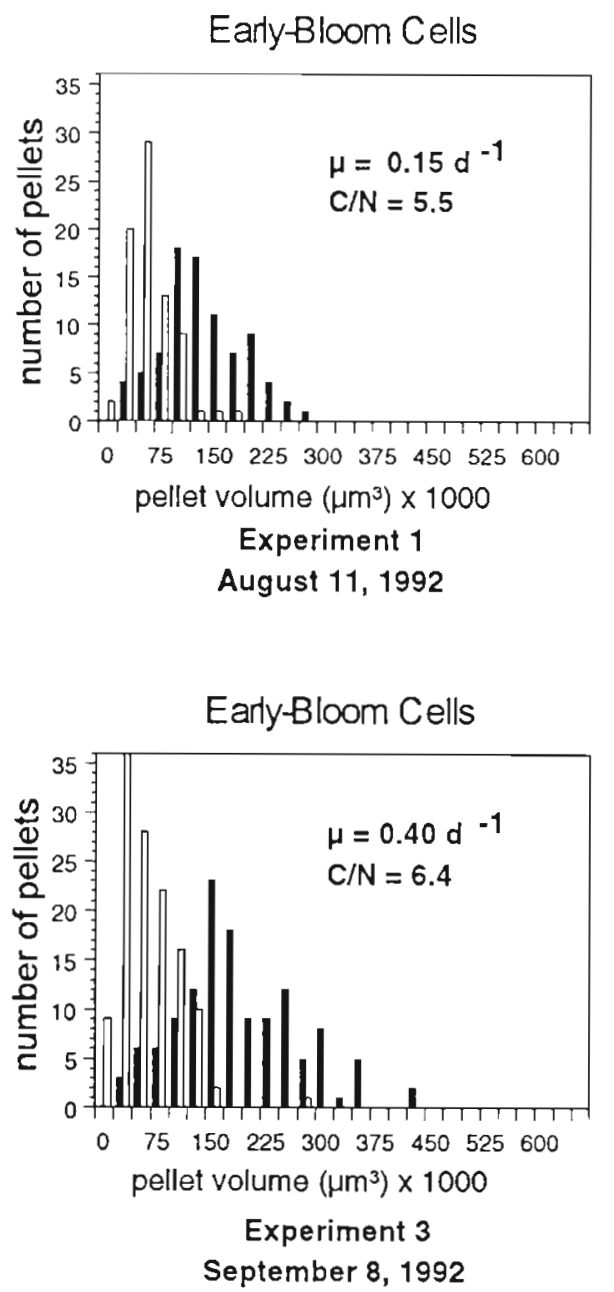
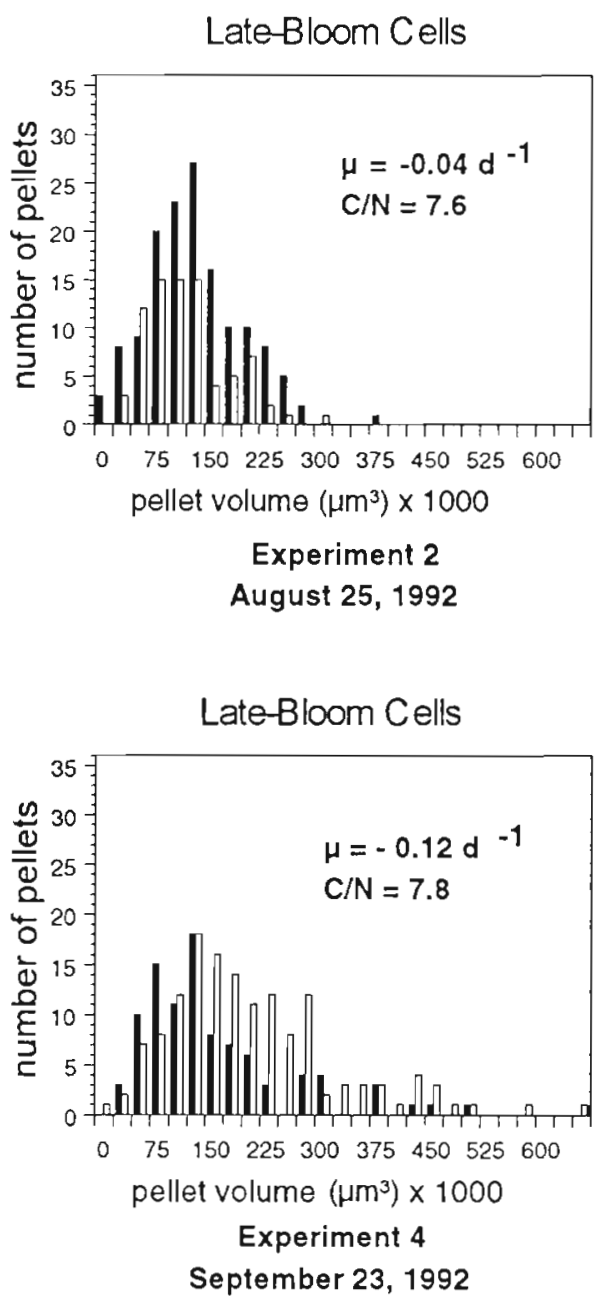

Fig. 4. Thalassiosira weissflogii. Frequency plots of estimated pellet volumes from the 4 large-scale pellet collection experiments. Empty bars: low food concentration; filled bars: high food concentration. $\mu$ and $\mathrm{C} / \mathrm{N}$ refer to the cell culture fed to the copepods

\section{Total fecal matter index}

The amount of fecal matter produced by a copepod is a function of its pellet production rate and the size of the pellets. Total fecal matter index, $\phi$, is defined as:

$$
\phi=\left(V_{1} \rho_{1}\right) / V_{c}
$$

where $V_{i}=$ total volume of fecal material produced by copepod $\mathrm{d}^{-1}$ (pellet production rate $\times$ average pellet volume), $p_{1}=$ density of pellets, and $V_{c}=$ volume of copepod (estimated from maximum length and width measurements of the prosome assuming a cylindrical shape). The pellet densities used in the calculation were averages measured in the large-scale pellet collections. A density of $1.17 \mathrm{~g} \mathrm{~cm}^{-3}$ was used when copepods fed on early-bloom cells and $1.14 \mathrm{~g} \mathrm{~cm}^{-3}$ when copepods fed on late-bloom cells. Maximum $\phi$ tended to be greater when food fed to copepods was representative of early-bloom conditions compared to latebloom conditions (Fig. 5). This trend was observed in all 3 experiments (Table 5).

\section{Carbon and nitrogen content of pellets}

Carbon and nitrogen content of pellets were not conclusive since nitrogen concentrations were below detection levels in some cases. We observed consistently higher volume-specific fecal carbon in the more densely packed pellets from LSPC Expts 1 \& 3 (rapidly growing cells) compared to the less dense pellets from LSPC Expts 2 \& 4 (slowly growing cells, Table 6 ). The $C / N$ ratio of pellets tended to be lower $(\sim 4)$ during early-bloom conditions compared to latebloom conditions $(\sim 7)$. 

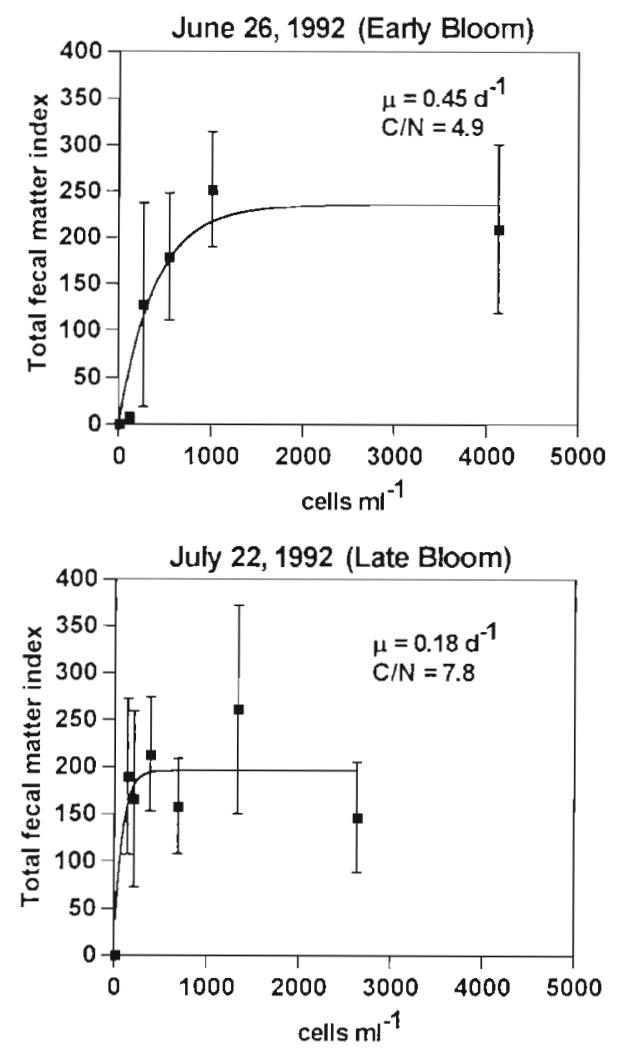

Fig. 5. Thalassiosira weissflogii. Total fecal matter index (see Eq. 4 in text) for the pellet production experiment done on June 26 and July 22, 1992. $\mu$ and $\mathrm{C} / \mathrm{N}$ refer to the cell culture fed to the copepods
Table 5. Thalassiosira weissflogii. Summary of Ivlev model fits to total fecal matter index [laverage volume per pellet $\times$ pellet production rate $x$ average density]/volume of copepod]. TFM $M_{\max }$ : maximum total fecal material index. Other parameters as in Table 2

\begin{tabular}{|c|c|c|c|c|c|}
\hline PP Expt & Date & $T F M_{\max }(\mathrm{SE})$ & $\alpha(\mathrm{SE})$ & $\mathrm{n}$ & $\mathrm{r}^{2}$ \\
\hline $1 \mathrm{a}$ & $\operatorname{Jan} 4$ & $238.81(92.87)$ & $1.9 \times 10^{-3}\left(1.3 \times 10^{-3}\right)$ & 18 & 0.57 \\
\hline $1 b$ & $\operatorname{Jan} 7$ & $180.12(26.61)$ & $3.9 \times 10^{-3}\left(1.5 \times 10^{-3}\right)$ & 18 & 0.76 \\
\hline $2 a$ & Jun 26 & $238.09(31.75)$ & $2.6 \times 10^{3}\left(1.0 \times 10^{-3}\right)$ & 27 & 0.62 \\
\hline $2 b$ & Jul 22 & $193.02(18.39)$ & $1.3 \times 10^{-2}\left(7.5 \times 10^{-3}\right)$ & 38 & 0.35 \\
\hline $3 a$ & Sep 4 & $360.55(107.20)$ & $0.5 \times 10^{-3}\left(0.3 \times 10^{-3}\right)$ & 25 & 0.70 \\
\hline $3 b$ & Sep 16 & $260.00(20.79)$ & $7.7 \times 10^{-3}\left(2.9 \times 10^{-3}\right)$ & 41 & 0.51 \\
\hline
\end{tabular}

Table 6. Thalassiosira weissflogii. Carbon and nitrogen content of pellets (note that mass of $\mathrm{C}$ and $\mathrm{N}$ is in terms of pellet volume). "Readings not

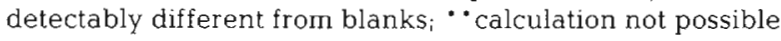

\begin{tabular}{|c|c|c|c|c|c|c|}
\hline $\begin{array}{c}\text { LSPC } \\
\text { Expt }\end{array}$ & Date & $\begin{array}{l}\text { Bloom } \\
\text { condition }\end{array}$ & $\begin{array}{c}\text { Food } \\
\text { cells } \mathrm{ml}^{-1}\end{array}$ & $\begin{array}{c}\mu g \mathrm{C} / \\
\text { pellet } \\
\text { volume } \\
\left(\mu \mathrm{m}^{3}\right) \\
\left(\times 10^{-7}\right)\end{array}$ & $\begin{array}{c}\mu g N / \\
\text { pellet } \\
\text { volume } \\
\left(\mu \mathrm{m}^{3}\right) \\
\left(\times 10^{-7}\right)\end{array}$ & $\begin{array}{c}\mathrm{C} / \mathrm{N} \\
\text { (weight) }\end{array}$ \\
\hline 1 & Aug 11 & Early & 314 & 25.0 & 7.8 & 3.2 \\
\hline 1 & Aug 11 & Early & 2405 & 24.0 & 5.8 & 4.3 \\
\hline 2 & Aug 25 & Late & 266 & 3.7 & 0.6 & 6.1 \\
\hline 2 & Aug 25 & Late & 1954 & 3.7 & 0.6 & 7.1 \\
\hline 3 & Sep 8 & Early & 271 & 9.0 & $\cdot$ & $\cdots$ \\
\hline 3 & Sep 8 & Early & 2301 & 3.0 & $\cdot$ & $\cdots$ \\
\hline 4 & Sep 23 & Late & 262 & 2.0 & - & $\cdots$ \\
\hline 4 & Sep 23 & Late & 2343 & 1.7 & $\cdot$ & $\cdots$ \\
\hline
\end{tabular}

\section{DISCUSSION}

Our experiments suggest that pellets change in a significant and predictable manner as food availability and food type change. In general, when copepods are fed algae of high quality (relatively higher growth rate, $\mu$, and lower $\mathrm{C} / \mathrm{N}$ ratio) they tend to produce a greater number of smaller, more dense pellets with greater volume-specific carbon content. When copepods are fed low-quality food they tend to produce fewer, larger, less dense pellets with lower volume-specific carbon content. Food concentration does not appear to affect pellet density, yet it does affect pellet volume and pellet production rate. Pellets tend to be fewer and smaller when copepods are fed low concentrations of algae compared to when they are fed high concentrations of algae, with the effect on pellet volume being more pronounced when algae are of high quality. These results are consistent with those of other workers. For example, Dagg \& Walser (1986) found that at algal concentrations of 129 to 181 cells $\mathrm{ml}^{-1}$ copepods exhibited full guts. Above this concentration, maxi- mum-sized pellets were produced. These data are similar to ours where we found that maximum fecal pellet volumes were achieved at cell concentrations between 129 and 178 cells $\mathrm{ml}^{-1}$.

Corner et al. (1972) and Paffenhöfer \& Knowles (1979) found functional response curves similar to ours when they plotted pellet production rate vs food concentration. Paffenhöfer \& Knowles (1979) found maximum pellet production rates between 30 and 200 pellets $\mathrm{d}^{-1}$ while the rates we observed were between 10 and 150 pellets $\mathrm{d}^{-1}$. Corner et al. (1972) reported a functional response for Calanus helgolandicus leveling off at approximately 90 pellets $\mathrm{d}^{-1}$ with a range of 5 to 100 pellets $d^{-1}$. Both Paffenhöfer \& Knowles' (1979) study and our study show a high variation in maximum pellet production rates. Ayukai \& Nishizawa (1986) also measured pellet production rates within our range. In addition, they calculated fecal material produced in terms of total volume and found these to be approximately twice those measured in this study. However, they studied Calanus pacificus pacificus, a copepod considerably larger than Acartia tonsa. They 
also found an increase in pellet production rate and total volume of fecal material produced as algal concentration increased. We also found a curvilinear increase in total fecal matter produced as algal concentration was increased (Fig. 5). In addition, a unique aspect of our study is that we observed a trend where greater total amounts of fecal matter were produced when algae fed to copepods were of higher quality compared to when algae were of lower quality (Fig. 5).

Volume-specific pellet carbon was greater when copepods were fed algae of higher quality. When copepods were fed lower-quality algae they produced pellets with lower volume-specific pellet carbon. The group of pellets we found to be more dense, i.e. those produced when copepods were fed algae of higher quality, also had greater volume specific-pellet carbon compared to pellets produced by copepods fed lowerquality algae. Our pellet carbon measurements were within the range presented by Morales (1987) reviewing measurements from several different studies. In addition, pellet $\mathrm{C} / \mathrm{N}$ ratios we obtained were comparable to those found by Morales (1987). Our data support Morales' (1987) conclusion that food concentration does not affect the $\mathrm{C} / \mathrm{N}$ ratio of pellets. However, food quality does appear to have an influence on the $\mathrm{C} / \mathrm{N}$ ratio of pellets. During early-bloom conditions the pellet $\mathrm{C} / \mathrm{N}(\sim 4)$ approximates the $\mathrm{C} / \mathrm{N}$ ratio of copepod tissue. During late-bloom conditions pellet $\mathrm{C} / \mathrm{N}$ is higher $(\sim 7)$, suggesting that copepods must preferentially conserve nitrogen in order to maintain the $\mathrm{C} / \mathrm{N}$ ratio required for their body tissue (Small et al. 1983).

\section{Simulation of a bloom}

Our algal cultures did not ever become severely nitrogen-limited, and in several cases the nitrogen per cell was actually greater in the 'nutrient-depleted' experiment. This might be explained by the cell's slight increase in size or by its tendency to store nitrogen intracellularly as outside supply of nitrogen decreases (Dortch et al. 1985). More likely, the cultures were silica-limited. If this were the case, the increase in the $\mathrm{C} / \mathrm{N}$ ratio might be explained by the relatively large increase in carbon per cell as oils are stored in deposits which is typical of silica-starved cells (Shifrin \& Chisholm 1981). This would explain the increase in $\mathrm{C} / \mathrm{N}$ ratio as the culture aged. Cultures used in experiments, which were meant to simulate a bloom in nature, had $\mathrm{C} / \mathrm{N}$ ratios which did not vary between experiments as much as we had hoped. However, blooms in nature may span a range of algal quality, as defined by $\mathrm{C} / \mathrm{N}$ ratio, similar to the range we were able to simulate in the laboratory (Sakshaug \& Olsen 1986).
The algae in the late-bloom experiments were more nutrient-depleted than the algae used in the experiments simulating early-bloom conditions. This is reflected in all of the growth rate estimates as well as in the $\mathrm{C} / \mathrm{N}$ ratios.

\section{Ecological implications}

Data from the pellet production experiments and large-scale pellet collection experiments suggest that the progress of a bloom appears to affect fecal pellets. Early in a bloom, nutrient-replete algae are available for copepods to eat. Copepods tend to produce comparatively small, but more densely packed fecal pellets when they have a relatively low concentration of highquality food. Perhaps these pellets, which have comparatively low sinking rates (Table 4 ), are important in recycling nutrients in the surface waters. Microbes and other larger animals are more likely to feed on small, slowly sinking pellets in the warmer surface waters (Honjo \& Roman 1978, Turner 1979, Lampitt et al. 1990, Noji et al. 1991). These pellets degrade and release nutrients into surface waters contributing to the maintenance of the bloom. Later, when algal concentrations increase, the largest, most dense pellets are produced. These pellets are most likely to transport nutrients rapidly from the euphotic zone due to their relatively short residence time in the euphotic zone. Eventually a bloom progresses into a dense population of slowly growing phytoplankton. During these latebloom conditions, fecal pellets continue to have relatively high sinking rates due to their comparatively large volumes (Table 4). These larger, although slightly less dense, pellets may also play an important role in removing materials from the surface layers, possibly contributing to the end of a bloom. Fig. 6 shows an idealized phytoplankton bloom and the relative size and density of fecal pellets that may occur when algae of different quantity and quality are present.

Although sinking phytoplankton may contribute more to the end of a bloom than sinking zooplankton fecal pellets in certain geographical regions, it must be noted that since algal cells may pass through copepod guts nearly intact (Bathmann \& Liebezeit 1986, Adrian 1987), algal aggregates may be indistinguishable from unraveling fecal pellets. We suggest that with the approach of a bloom's end, the conditions are favorable for the production of large, although comparatively less dense, relatively rapidly sinking pellets. Alone, or in the form of aggregates with senescent, possibly more sticky, algal cells (Kiørboe et al. 1990), they may contribute to a greater flux of materials from the photic zone and play an important role in benthic/pelagic coupling. 


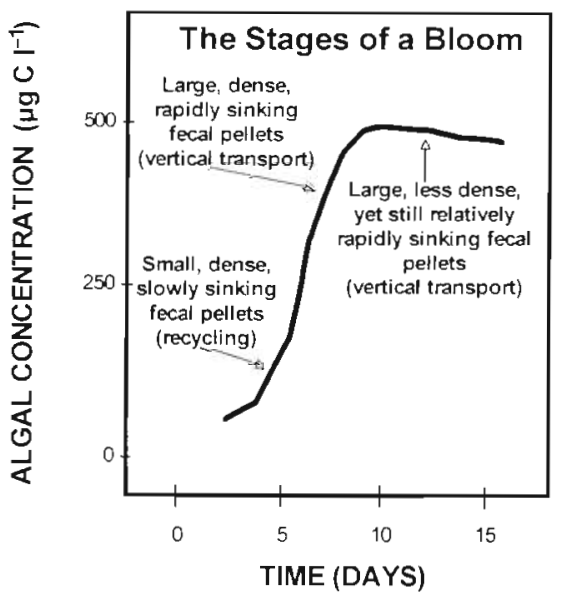

Fig. 6. Thalassiosira weissflogii. Illustration of an idealized phytoplankton bloom and the relative size and density of fecal pellets that may occur when algae of different quantity and quality are present. Parentheses denote possible role pellets may play in transport of materials

In addition to changes in fecal pellet characteristics, copepod populations also change. Based on the classical increase in copepod population during a bloom, the amount of fecal material contributing to the vertical flux may increase by an order of magnitude from the beginning to the end of the bloom (Table 7). Even though more fecal carbon per copepod is produced early in a bloom, the increase in copepod abundance may have a great influence on the amount of fecal carbon contributing to the overall vertical flux.

Table 7 Thalassiosira weissflogii. Estimated fecal pellet contribution to carbon flux under early-bloom and late-bloom conditions. Factors 1,3 , and 4 are averages determined from this study. Factor 2 represents typical daily concentrations of female Acartia tonsa during the fall bloom in Long Island Sound, New York, USA (Dam 1989). These calculations were based on the following equation: Flux $\left(\mu \mathrm{g} \mathrm{C} \mathrm{m} \mathrm{C}^{-2} \mathrm{~d}^{-1}\right)=\mathrm{Con}$ centration $\left(\mu \mathrm{g} \mathrm{C} \mathrm{m}{ }^{-3}\right) \times$ Sinking rate $\left(\mathrm{m} \mathrm{d}^{-1}\right)$

\begin{tabular}{|c|c|c|}
\hline Factor & Early bloom & Late bloom \\
\hline 1. Sinking rate $\left(\mathrm{m} \mathrm{d}^{-1}\right)$ & 10 & 20 \\
\hline $\begin{array}{l}\text { 2. Acartia tonsa concentration } \\
\text { (ind } \mathrm{m}^{-3} \text { ) }\end{array}$ & 100 & 5000 \\
\hline $\begin{array}{l}\text { 3. Volume of fecal material } \\
\text { produced } \\
\left(\mu \mathrm{m}^{3} \text { female } \mathrm{d}^{-1}\right)\end{array}$ & $1.5 \times 10^{7}$ & $1.0 \times 10^{7}$ \\
\hline $\begin{array}{l}\text { 4. Carbon per volume of } \\
\text { fecal material }\left(\mu g \mathrm{C} \mathrm{m}^{-3}\right)\end{array}$ & $25 \times 10^{-7}$ & $5 \times 10^{-7}$ \\
\hline Total $\left(\mu \mathrm{g} C \mathrm{~m}^{-2} \mathrm{~d}^{-1}\right)$ & $3.75 \times 10^{4}$ & $5.0 \times 10^{5}$ \\
\hline
\end{tabular}

In conclusion, our research shows that over the course of a simulated phytoplankton bloom, pellet production rates and several pellet characteristics change in a predictable manner. These changes may have a great impact on the amount of fecal material contributing to the downward flux of carbon in the oceans.

Acknowledgements. Research supported by NSF grant OCE9022418 and a research grant from the Research Foundation of the University of Connecticut. We thank D. Drapeau, M. Powell, and $X$. Zhang for laboratory and field assistance; $D$. Lee for statistical advice; T. Kiørboe, L. Small, J. Turner, and an anonymous reviewer for comments and suggestions that improved the quality of the manuscript. This is contribution 260 from the Marine Science Institute of the University of Connecticut.

\section{LITERATURE CITED}

Adrian, R. (1.987). Viability of phytoplankton in fecal pellets of two cyclopoid copepods. Arch. Hydrobiol. 110: 321-330

Alldredge, A. L., Gotschalk, C. C., MacIntyre, S. (1987). Evidence for sustained residence of macrocrustacean fecal pellets in surface water of southern California. Deep Sea Res. 34: 1641-1652

Angel, M. V (1984). Detrital organic fluxes through pelagic ecosystems. In: Fasham, M. J. (ed.) Flows of energy and materials in marine ecosystems: theory and practice. Plenum Press, New York, p. 475-516

Ayukai, T., Nishizawa, S. (1986). Defecation rate as a possible measure of ingestion rate of Calanus pacificus pacificus (Copepoda: Calanoida). Bull. Plankton Soc. Japan 33: 3-10

Bathmann, U., Liebezeit, G. (1986). Chlorophyll in copepod faecal pellets: changes in pellet numbers and pigment content during a declining Baltic spring bloom. P.S.Z.N. I: Mar. Ecol. 7: 59-73

Bathmann, U. V., Noji, T T., Voss, M., Pelnert, R. (1987). Copepod fecal pellets: abundance, sedimentation and content at a permanent station in the Norwegian Sea in May/June 1986. Mar. Ecol. Prog. Ser. 38: 45-51

Bienfang, P. K. (1980). Herbivore diet affects fecal pellet settling. Can. J. Fish. Aquat. Sci. 37: 1352-1357

Corner, E. D. S., Head, R. N., Kilvington, C. C. (1972). On the nutrition and metabolism of zooplankton VIII. The grazing of Biddulphia cells by Calanus helgolandicus. J. mar. biol. Ass. U.K. 52: 847-861

Dagg, M. J., Walser, W. E. Jr (1986). The effect of food concentration on fecal pellet size in marine copepods. Limnol Oceanogr. 31: 1066-1071

Dam, H. G. (1989). The dynamics of copepod grazing in Long Island Sound Ph.D. dissertation, State University of New York at Stony Brook

Dortch, Q., Clayton, J. R., Thoresen, S. S., Cleveland, J. S., Bressler, S. L., Ahmed, S. I. (1985). Nitrogen storage and use of biochemical indices to assess nitrogen deficiency and growth rate in natural plankton populations. J. mar. Res. 43: 437-464

Durbin, A. G., Durbin, E. G. Wlodarczyk, E. (1990). Diel feeding behavior in the marine copepod Acartia tonsa in relation to food availability. Mar, Ecol. Prog. Ser. 58: 23-45

Fowler, S. W. Small, L. (1972). Sinking rates of euphausid fecal pellets. Limnol. Oceanogr. 17: 293-296 
Guillard, R. R. L. (1975). Culture of phytoplankton for feeding marine invertebrates. In: Smith, W. L., Chanley, M. H. (eds.) Culture of marine invertebrates. Plenum Press, New York, p. 29-60

Honjo, S., Roman, M. R. (1978). Marine copepod fecal pellets: production, preservation and sedimentation. J. mar. Res. 36: $45-57$

Jacobsen, T. R., Azam, F. (1984). Role of bacteria in copepod fecal pellet decomposition, colonization, growth rates and mineralization. Bull. mar. Sci. 35: 495-502

Kiorboe, T., Andersen, K., Dam, H. G. (1990). Coagulation efficiency and aggregate formation in marine phytoplankton. Mar. Biol. 107: 235-245

Komar, P. D., Morse, A. P, Small, L. F., Fowler, S. W. (1981). An analysis of sinking rates of natural copepod and euphausiid fecal pellets. Limnol. Oceanogr. 26: 172-180

Lampitt, R., Noji, T., von Bodungen, B. (1990). What happens to zooplankton fecal pellets? Implications for material flux. Mar. Biol. 104: 15-23

Legendre, L. (1990). The significance of microalgal blooms for fisheries and for the export of particulate organic carbon in oceans. J. Plankton Res. 12: 681-699

Morales, C. E. (1987). Carbon and nitrogen content of faecal pellets: effect of food concentration and feeding behavior. Mar. Ecol. Prog. Ser. 36: 107-114

Noji, T T (1991). The influence of microzooplankton on vertical particulate flux. Sarsia 76:1-19

Noji, T T., Estep, K. W., Macintyre, F., Norrbin, F. (1991). Image analysis of faecal material grazed upon by three species of copepods: evidence for coprorhexy, coprophagy and coprochaly. J. mar biol. Ass. U.K. 72: 465-480

Paffenhöfer, G. A., Knowles, S. C. (1979). Ecological implications of fecal pellet size, production and consumption by copepods. J. mar. Res. 37: 35-49

Penry, D., Frost, B. W. (1991). Chlorophyll a degradation by Calanus pacificus: dependence on ingestion rate and digestive acclimation to food resources. Limnol. Oceanogr 36: $147-159$

Roy, S., Poulet, S. A. (1990). Laboratory study of the chemical composition of aging copepod fecal material. J. exp. mar. Biol. Ecol. 135: 3-18

Sakshaug, E., Olsen, Y. (1986). Nutrient status of phytoplankton blooms in Norwegian waters and algal strategies for nutrient competition. Can. J. Fish. Aquat. Sci. 43: 389-396

Schrader, H. (1971). Fecal pellets: role in sedimentation of pelagic diatoms. Science 174: 55-57

Schwinghamer, P., Anderson, D. M., Kulis, D. M. (1991). Separation and concentration of living dinoflagellate resting

This article was presented by M. R. Landry (Senior Editorial Advisor), Honolulu, Hawaii, USA cysts from marine sediments via density-gradient centrifugation Limnol. Oceanogr. 36: 588-592

Shifrin, N., Chisholm, S. W. (1981). Phytoplankton lipids: interspecific differences and effects of nitrate, silicate and light-dark cycles. J. Phycol. 17: 374-384

Small, L. F., Ellis, S. G. (1992). Fecal carbon production by zooplankton in Santa Monica Basin: the effects of body size and carnivorous feeding. Prog. Oceanogr 30: $197-221$

Small, L. F., Fowler, S. W., Moore, S. A., LaRosa, J. (1983). Dissolved and fecal pellet carbon and nitrogen release by zooplankton in tropical waters. Deep Sea Res. 30: $1199-1220$

Small, L. F., Fowler, S. W., Ünlü, M. Y. (1979). Sinking rates of natural copepod fecal pellets. Mar. Biol. 51: 233-241

Small, L. F., Knauer, G. A., Tuel, M. D. (1987). The role of sinking fecal pellets in stratified euphotic zones. Deep Sea Res. 34: 1705-1712

Sokal, R. J., Rohlf, F. J. (1981). Biometry. W. H. Freeman and Co., San Francisco

Statgraphics User's Guide (1986). Statistical Graphics Corporation, Rockville, $\mathrm{MD}$

Stearns, D. E. (1986). Copepod grazing behavior in simulated natural light and its relation to nocturnal feeding. Mar Ecol. Prog. Ser. 30: 65-76

Tanoue, E. (1985a). Organic chemical composition of fecal pellets of krill Euphausia superba Dana. I. Lipid composition. Trans. Tokyo U. Fish. 6: 125-134

Tanoue, E. (1985b). Organic chemical composition of fecal pellets of krill Euphausia superba Dana. II. Amino acid composition. Trans. Tokyo Univ. Fish. 6: 135-138

Tanoue, E., Hara, S. (1986). Ecological implications of fecal pellets produced by the Antarctic krill Euphausia superba in the Antarctic Ocean. Mar. Biol. 91: 359-369

Turner, J. T. (1977). Sinking rates of fecal pellets from the marine copepod Pontella meadiii. Mar. Biol. 40: 249-259

Turner, J T (1979). Microbial attachment to copepod fecal pellets and its possible ecological significance. Trans. Am. Microsc. Soc. 98: 131-135

Turner, J. T., Ferrante, J. G. (1979). Zooplankton fecal pellets in aquatic ecosystems. BioSci. 29: 670-677

Urban, J., Diebel, D., Schwinghamer, P. (1993). Seasonal variations in the densities of fecal pellets produced by Oikopleura vanhoeffeni (C. Larvacea) and Calanus finmarchicus (C. Copepoda). Mar. Biol. 117: 607-614

Urrère, M. A., Knauer, G. A. (1981). Zooplankton fecal pellet fluxes and vertical transport of particulate organic material in the pelagic environment. J. Plankton Res. 3: 369-385

Manuscript first received: March 8, 1994

Revised version accepted: June 20, 1994 